\title{
Mantra Batalah Sebagai Tradisi Lisan pada Masyarakat Suku Dayak di Kabupaten Landak Kalimantan Barat (Perspektif Kajian Antropolinguistik)
}

\author{
Suparman ${ }^{1}$, Harun Ahmad ${ }^{2}$, Yunita Anas Sriwulandari ${ }^{3}$ \\ 1,2,3 IKIP Budi Utomo Malang, Indonesia \\ E-mail: uparmanlacot12@gmail.com, harun.a.sangaji@gmail.com, cikyun2906@gmail.com
}

\begin{abstract}
Article Info
Article History

Received: 2021-05-12

Revised: 2021-07-22
\end{abstract}

Published: 2021-08-13

\section{Keywords:}

Form of performance;

Batala ritual;

Antropolinguistik.

\begin{abstract}
The Batala ritual ceremony (the ceremony for naming a baby) has a very interesting form of performance, meaning, function, value, and norm if studied from an anthropolinguistic perspective. Thus, this study aims to describe the form of performance, meaning, function, value, and norm of the Batalah mantra in the Dayak tribal community in Landak Regency, West Kalimantan. The approach used is a qualitative research approach with anthropolinguistic analysis methods. The steps taken in conducting the analysis are by identifying to identify it which is then analyzed and concluded. After being analyzed using these approaches and methods, the following results were obtained. First, the mantra at the Batalah traditional ceremony is a ceremony carried out to give a name to a baby who has been born in order to have protection from God which in the Kanayantn Dayak language is called "Jubata". The Batalah Mantra has a transcendent dimension (beyond all human capabilities) because life in the real world is always related between God and humans, humans and nature. The performance of the Batala mantra in Pauh Village, Landak Regency, West Kalimantan in the process takes the form of calling shamans (smart people) and offerings. Second, the meaning contained in the Batala mantra is as giving a valid name in the eyes of God (Jubata) and in the eyes of the ancestors, as giving a valid name in real human life, and as a protective name. The functions of mantras include as a means of ratifying institutions and culture, as a means of maintaining community norms and as a means of traditional medicine. The Batalah Mantra for the people of Pauh Village, Landak Regency, West Kalimantan, functions as a communication tool with God (Jubata), a communication tool with ancestors, a form of protection for babies, a form of legal naming, maintaining a sense of kinship, and as a form of preserving customs and culture. The value of the Batala mantra for the people of Pauh Village, Landak Regency, West Kalimantan is categorized into two, namely religious values and social values. The norms in the Batala mantra are the rules contained in every mantra words when reading the mantra. Suggestions for further research, namely research on mantras in Batalah ritual ceremonies can be studied from a perspective other than an anthropolinguistic perspective, for example a semiotic perspective. In addition, to obtain maximum results in conducting literary research, especially old literature, accuracy in choosing data sources is something that is necessary.
\end{abstract}

\section{Artikel Info}

Sejarah Artikel

Diterima: 2021-05-12

Direvisi: 2021-07-22

Dipublikasi: 2021-08-13

Kata kunci:

Bentuk Performansi; Ritual Batala;

Antropolinguistik.

\begin{abstract}
Abstrak
Upacara ritual Batalah (upacara pemberian nama bayi) memiliki bentuk performansi, makna, fungsi, nilai, dan norma yang sangat menarik jika dikaji dalam perspektif antropolinguistik. Dengan demikian, penelitian ini bertujuan mendeskripsikan bentuk performansi, makna, fungsi, nilai, dan norma mantra Batalah pada masyarakat suku Dayak di Kabupaten Landak Kalimantan Barat. Pendekatan yang digunakan adalah pendekatan penelitian kualitatif dengan metode analisis antropolinguistik. Langkah yang ditempuh dalam melakukan analisis adalah dengan cara mengidentifikasi untuk menemukenalinya yang selanjutnya dianalisis dan disimpulkan. Setelah dianalisis dengan menggunakan pendekatan dan metode tersebut, diperoleh hasil-hasil sebagai berikut. Pertama, mantra pada upacara adat Batalah merupakan upacara yang dilakukan untuk pemberian nama pada bayi yang telah lahir agar memiliki perlindungan dari Tuhan yang dalam bahasa Dayak Kanayantn disebut "Jubata". Mantra Batalah berdimensi transcendent (di luar segala kesanggupan manusia) karena kehidupan di dunia nyata selalu berhubungan antara Tuhan dan manusia, manusia dan alam. Performansi mantra Batalah di Desa Pauh Kabupaten Landak Kalimantan Barat dalam prosesnya berbentuk pemanggilan dukun (orang pintar) dan sesajen. Kedua, makna yang terkandung dalam mantra Batalah adalah sebagai pemberian nama yang
\end{abstract}


sah di mata Tuhan (Jubata) dan di mata Nenek Moyang, sebagai pemberian nama yang sah di kehidupan nyata manusia, dan sebagai nama pelindung. Fungsi mantra di antaranya sebagai alat pengesahan pranata dan kebudayaan, sebagai alat pemeliharaan norma-norma masyarakat dan sebagai alat pengobatan tradisional. Mantra Batalah bagi masyarakat Desa Pauh Kabupaten Landak Kalimantan Barat berfungsi sebagai alat komunikasi dengan Tuhan (Jubata), alat komunikasi dengan nenek moyang, bentuk perlindungan pada bayi, bentuk pemberian nama yang sah, menjaga rasa kekeluargaan, dan sebagai bentuk pelastarian adat dan budaya. Nilai mantra Batalah bagi masyarakat Desa Pauh Kabupaten Landak Kalimantan Barat dikategorikan menjadi dua, yaitu nilai religious dan nilai sosial. Norma dalam mantra Batalah merupakan aturan yang terdapat di setiap kata-kata mantra ketika dalam pembacaan mantra. Saran untuk penelitian selanjutnya yaitu penelitian terhadap mantra dalam upacara ritual Batalah dapat dikaji dari perspektif selain perspektif antropolinguistik, misalnya perspektif semiotik. Selain itu, untuk memperoleh hasil yang maksimal dalam melakukan penelitian sastra khususnya sastra lama, ketepatan dalam memilih sumber data adalah sesuatu yang niscaya.

\section{PENDAHULUAN}

Indonesia merupakan sebuah bangsa yang kaya akan kebudayaannya, kebudayaan tersebut berasal dari berbagi suku yang menetap. Setiap suku yang menetap masing-masing memiliki adat-istiadat yang berbeda sesuai letak geografisnya. Upacara ritual adat merupakan salah satu tradisi dari masyarakat tradisional yang menganggap memiliki nilai-nilai mistis yang sangat kuat untuk dipercaya bagi masyarakat pendukungnya sehingga sangat erat kaitannya dengan antara alam dan manusia ini ialah suatau yang tidak bisa di tolak oleh manusia, hubungan ini karena memiliki mempunyai nilai sakral yang kuat. Suku Dayak merupakan salah satu suku yang terletak di Provinsi Kalimantan Barat, yang mempunyai banyak bahasa daerah dan budaya yang bermacam ragam, diamana masyarakat suku Dayak pada awal mulanya hidup dan berkembang di perdalaman hutan Kalimantan dengan suhu tropis. Dalam upacara Batalah ini disajikan salah satau sesajen yang diperlukan dalam pemberian nama yaitu: Piring Tua, Ayam kampung, Daun Sirih, Beras, keranjang, Ayam Kampung dan Telur, Besi dan Buah Pinang kuat (Priskila, 2010:14; Yogi, dkk., 2019:3-4; Munawarroh, 2016:1).

Mantra sebagai salah satu jenis puisi lama dengan fitur-fiturnya sangat menarik sebagai interdisipliner antara bahasa dan perilaku berbicara. Maka dari itu bagaimana penyampaian bahasa Mantra Batalah sebagai tradisi lisan pada masyarakat Suku Dayak di Kabupaten Landak Kalimantan Barat. Dengan menggunakan kajian antropolinguistik mampu mengemukaan variasi dan penggunaan bahasa dalam penyampaian mantra Batalah yang hubungannya dengan perkembangan waktu, perbedaan tempat komunikasi, sistem kekerabatan, pengaruh kebiasaan etnik, kepercayaan, etika bahasa, adat istiadat, dan pola-pola kebudayaan lain dari suatu suku bangsa (Sibarani dalam Manik, 2019:7).

Perspektif kajian antropolinguistik pada mantra Batalah mampu mengupas permasalahan yang terjadi dengan menganalisis atau melihat bentuk performansi, makna, fungsi, nilai, dan norma mantra Batalah sebagai tradisi lisan pada masyarakat Suku Dayak di Kabupaten Landak Kalimantan Barat, Berdasarkan penelitian ditemukan bentuk performansi yaitu memanggil dukun (orang pintar) yang dipercayai untuk melaksanakan proses upacara Batalah, macammacam sesajen, dan proses pelaksanaan upacara adat Batalah. Untuk memperkuat pernyatan tersebut di temukan makna, fungsi, nilai, dan norma yang terdapat di dalam mantra Batalah sebagai tradisi lisan pada masyarakat Suku Dayak di Kabupaten Landak Kalimantan Barat yang mampu memberikan penjelasan mengenai fungsi di kehidupan nyata, dengan tujuan memperoleh deskripsi atau gambaran objektif tentang bahasa dalam mantra Batalah sebagai tradisi lisan, agar pembaca dapat dapat memahami kehidupan sosial dan ciri-cirikemasyarakatan untuk di pecahkan dan direfleksikan dalam kehidupan nyata.

\section{METODE PENELITIAN}

Pendekatan penelitian ini adalah pendekatan penelitian kualitatif. Penggunaan pendekatan penelitian kualitatif ini sesuai dengan ciri-ciri penelitian kualitatif yang dinyatakan Bogdan dan Biklen (Jumadi, dkk., 2017:38), yaitu: menggunakan latar alami sebagai sumber data langsung dan peneliti sebagai instrumen utama, bersifat deskriptif, lebih memperhatikan proses daripada hasil, cenderung menganalisis data secara induktif, dan makna merupakan perhatian utama. Metode yang digunakan dalam penelitian 
ini adalah metode penelitian deskriptif-kualitatif, yaitu penelitian yang berupaya menggambarkan atau melukiskan situasi tertentu berdasarkan data yang diperoleh secara terperinci sesuai permasalahan yang ditetapkan dalam penelitian. Teknik dalam pengumpulan data pada penelitian ini menggunakan teknik observasi, domumentasi, dan wawancara. Teknik observasi digunakan untuk memperoleh data terkait dengan penggunaan mantra Batalah dengan alat yang digunakan ialah kamera digital merk Xioami Mi 10 Ultra yang berupa gambar. Data yang diperoleh dari sumber data lisan melalui observasi langsung dan wawancara mendalam dengan informan. Salah seorang informan kunci yang dikenal selalu mempraktikan mantra Batalah adalah Bapak Andot berusia 64 tahun beliau penduduk asli Desa Barinang, Kecamatan Sompak, Kabupaten Landak, Kalimantan Barat. Maka teknik yang digunakan untuk menganalisis dengan teknik etnografi dan model interaktif. Alur pelaksanaan penelitian etnografi dimulai dengan memilih situasi sosial, melaksanakan observasi, mencatat hasil observasi, dan hasil wawancara sebagaimana dinyatakan Spradley (Jumadi, dkk., 2017:39).

\section{HASIL DAN PEMBAHASAN}

Masyarakat Suku Dayak khususnya Desa Pauh Kabupaten Landak Kalimantan Barat sudah lama mengenal adanya upacara adat Batalah yang dipraktikan oleh masyarakat setempat, hal ini dilakukan sebagai salah satu cara untuk meneruskan adat-istiadat dari nenek moyang. Tradisi upacara adat Batalah menandakan bahwa tradisi ini dipandang sebagai tradisi yang memiliki bentuk performansi yang bermanfaat oleh masyarakat. Sebagaimana menurut Bapak Andot selaku orang yang dikenal selalu mempraktikan mantra Batalah bahwa upacara Batalah merupakan suatu kegiatan pemberian Nama pada bayi yang dilakukan bahkan sangat diyakini oleh masyarakat suku Dayak di Desa Pauh Kabupaten Landak Kalimantan Barat. Upacara adat Batalah dalam kegiatannya memiliki makna, fungsi, nilai dan Norma yang sakral. Dalam bentuk performansi upacara Batalah sangatlah terbuka serta memiliki arti bagi masyarakat suku Dayak di Desa Pauh Kabupaten Landak. Performansinya berdimensi transcendent (di luar segala kesanggupan manusia) karena kehidupan di dunia nyata selalu berhubungan antara Tuhan dan manusia, manusia dan alam.

Bentuk performansi Batalah di Desa Pauh Kabupaten Landak Kalimantan Barat ada berberapa hal yang perlu dipersiapkan sebelum kegiatan upacara itu dilakukan antara lain yaitu: (1) memanggil dukun (orang pintar) yang dipercayai untuk melaksanakan proses upacara Batalah, (2) macam-macam sesajen, (3) proses pelaksanaan upacara adat Batalah.

\section{A. Memanggil Dukun (Orang Pintar)}

Pemanggilan merupakan bentuk tanda jadi bahwa dukun tersebut bersedia untuk melakukan pelaksanaan pembacaan mantra dalam upacara Batalah dari awal hingga akhir upacara tersebut. Bapak Andot penduduk asli Desa Pauh selaku orang yang memiliki kemampuan supranatural bisa melihat, berkomunikasi dan memahami arwah dan alam gaib, kemampuan itu dipergunakan untuk membantu masyarakat dalam berbagi upacara seperti, Upacara Batalah (pemberian nama pada bayi), Upacara Babore (berobat tradisional), Upacara Nyangahatn (pembacaan mantra) dan Upacara Naik Dango (gawai hasil padi) dan lain-lain, Pemanggilan dukun saat upacara Batalah dilakukan saat sore atau malam hari, sehari sebelum pelaksanaan upacara Batalah, hal ini dilakukan agar dukun tersebut bisa mempersiapkan diri untuk berkomunikasi dengan arwah. Peran dukun ini sangat penting dalam pelaksanaan upacara Batalah, karena lancar apa tidaknya upacara tersebut itu bergantung pada dukun (orang pintar).

\section{B. Menyajikan Sesajen}

Sesajen pada upacara mantra Batalah digunakan sebagai alat komunikasi dukun (orang pintar) kepada arwah-arwah hal ini dilakukan agar penyampaian apa yang diminta oleh dukun bisa terkabulkan. jenis sesajen upacara mantra Batalah berbeda dengan jenis sesajen upacara-upacara adat lain. Jenis sesajen dan maknanya pada upacara mantra Batalah di Desa Pauh Kabupaten Landak Kalimantan Barat, yaitu: Ayam Jago memiliki makna sebagai kegagahan agar anak tersebut diharapkan seperti gagahnya ayam jago, Kendi memiliki makna sebagai wadah yang digunakan untuk menampung rezeki yang diberikan Tuhan pada anak, Air putih Satu Gelas memiliki makna sebagai penysucian pada anak, Lemang (Poe) dengan bentuk memanjang menggunakan bambu yang berisi beras pulut dicampurkan air santan dan garam memiliki makna sebagai penyemangat kehidupan, Besi yang memiliki makna agar anak tersebut kuat terhadap apapun, Kue cucur (Tumpi) berbahan dasar tepung memiliki makna agar anak tersebut dapat bersifat halus/baik, Pelita (lilin) memiliki makna agar anak tersebut mendapat penerangan dari Sang Maha Kusa, Kue Pulut (Bontokng) memiliki makna sebagai rezeki didapatkan yang dilipat gandakan seperti halnya lipatan pada sesajen Bontokng yang memiliki lipatan tebal berisi nasi, 
Daun Sirih memiliki makna agar kelak anak dewasa bisa hidup di mana saja, seperti halnya mengambarkan daun sirih bisa hidup dan merayap di mana saja, Rokok Daun memiliki sebagi pengusir roh halus yang ingin berbuat jahat, Tembakau memiliki makna agar anak tersebut memiliki tali kehidupan yang baik dengan orang lain, Beras memiliki makna sebagai penggambaran agar nama yang telah diberikan pada anak jangan di ganggu, Telur ayam mempunyai makna sebagai persatuan di antara mereka atau agar anak tersebut dapat membawa persatuan di antara warga, dan Buah Pinang yang digunakan sebagai penentu pemilihan nama pada bayi dengan makna warna kehidupan yang artinya nama yang sudah dipilih itu memiliki berkat yang kuat seperti hal nya warna merah.

\section{Proses Pelaksanaan Upacara Adat Batalah}

Proses dalam pelaksanaan upacara Batalah merupakan proses terlaksananya kegiatan tersebut, proses ini yang ditunggu oleh orang tua bayi setelah selesai mempersiapkan semuanya. Hal yang dilakukan dalam proses ini seperti pembacaan mantra yang dilakukan oleh dukun (orang pintar), proses pembacaan mantra dilakukan dengan keadaan yang tenang agar dalam penyampaian atau pembacaan bisa diterima oleh Tuhan yang dalam bahasa Suku Dayak disebut dengan "Jubata". Pembacaan atau proses Batalah dilakukan pada tempat kediaman orang tua bayi, agar sekaligus bisa memberkati.

\section{Mantra Batalah (Pemberian Nama Pada Bayi)}

"Asa, dua, talu, ampat, lima, anam, tujuh. Mata'ari saparati narabitn untukng tuah ka'dirik. Nian aku mao naburant baras banyu kuning onto'ene diri ka`tanyung, gente nibungan saparati jubata. Buke aku ngaluma ngalangko urang nang dah ba idup lama. Mak'alum aku kamunda enek nang jadi panabur baras untok kitak page waris samadiant. Saru nyimpado dah sampe ka'dian, tujuh bege baras banyu kuning nang batarakng batampok ka`matari, ka`bulant ba`kabintkng nang dah mao muokant muhanya untok dirik nang ka dian. Barakat nek cante nang udah mare dirik adat unto katurunannya, biar dirik manjadi manusia nang gagas ka'dunia nian. Asa, dua, talu, ampat, lima, anam, tujuh, page waris samadiant nang udah bakomo nyiapant Baras, Pinang, Manok, Talo, Basi, Ai, Karake, Rokok, Palita, unto palangkapant Batalah anak diri nian. Ao,, nian baras banyu, man barakat nang mampu nawari barang nang kuat, nang ba'macam akibat ulah talino nang baci. Ao,, ampeant mao ngampekant'a ai pake daunk bunga salaseh nang bagelo saparati kamunda nang baru atang ka'dunia, moga ka'turunan nek moyang dirik nian ngincang repo ka 'mae ia ampus, nian barakat Jubata. $A$,, nian agik aku numpahant ai ka cawan balek unto nasah ujung koekng, kapala, bagurah biar baraseh. Kitak nang ku saru simpado atang repo bakomo ba'page waris, samoga jubata ngalindungki rumah tangga nang gagas man ka'mae ia idup. Aaa,, nian jubata pasambahant ku naikant ka'tampat nang ting'gi amapa saruga kitak masar palajuk palango. A, nian agik aku bapinta bamang mudahan kamunda nian saparati gulita nang nyala kade malam atang, man lea manaok laki nang barani ka 'paridupant nian. Nian agik aku mare conteng daerah manok manta ame ngupat gede nian dah dimare agiant sekok-sekok. $A$, , kade ada urangk nang nanak tantu rudu ame ngaco, nian udah ada agiant saparati, timako, rokok, kapur, karakek nang ana unto kitak makant kita masar untukng tuah. Ampeant ku mare saroas poe saparati langir nang dipagunaan panyangah rumah ame sampe tanyuk ka babah. Asa, dua, talu, ampat, lima, anam, tujuh, aku bakabar ka jubata minta banto ampeant mao nalah, a kamunda nama nang gagas saparati pajalanan idupnya ana, nian namanya nang udah dinyiapant (Fransiskus Januardi). Ao'ta jubata Batalah nian udah sampe ka pangabisant, ampeant mao balara man page samadiant, kade ada simpadoku nang salah saparati late nang nyaru ujant, aku minta ampon ka kitak jubata. Aa, nian aku batarima kasih batol ka Jubata, sampe ampeant boh pamintaant ku ka kita jubata. Asa, dua, talu, ampat, lima, anam, tujuh".

Artinya: "Satu, dua, tiga, empat, lima, enam, tujuh matahari terbit seperti memperlihatkan rezeki pada kita. Sekarang aku mau menaburkan beras kuning pada nenek kita yang ada di rawarawa Nibungan seperti Tuhan. Bukan maksudku mendahuluhi orang yang sudah tua hidup lama.Maklum aku orang muda yang jadi penabur untuk kalian saudaraku. Kini panggilan sudah datang, ini tujuh biji beras kuning untuk mohon restu pada matahari, pada bulan, pada bintang, yang sudah mau melihatkan mukanya disini. Berkat nenek yang cantik sudah memberikan keturunan, biar kita menjadi manusia yang baik di dunia. Satu, dua, tiga, empat, lima, enam, tujuh, sanak saudara yang sudah berkumpul mempersiapkan Beras, Pinang, Ayam, Telur, Besi, Air, Sirih, Rokok, Lilin, sebagai perlengkapaan (Batalah) pemberian nama pada bayi hari ini. Ya,, ini beras, dengan berkat bisa menawari panyakit yang kuat, yang jahat akibat perbuatan manusia yang benci. Ya,, sekarang mau menaburkan air pakai daun bunga selasih yang bersih seperti anak yang baru datang ke dunia semoga keturunan 
nenek moyang kita ini bisa memberikan kebahagian kemana saja dia pergi, ini berkat Tuhan. A,,, ini lagi aku menuangkan air dalam gelas untuk mencuci ujung kelingking, kepala, kumukumur biar bersih. Kalian yang ku undang dengan bahagia, datang berkumpul dengan sanak saudara, semoga Tuhan memberkati rumah tangga yang baik ke mana pun tinggal. Aaa,,, ini Tuhan persembahan ku antarkan ke gunung yang tinggi seperti surga semoga kalian puas atas dengan apa yang kami persembahkan. A, ini lagi aku memohon doa semoga anak ini seperti lilin (pelita) yang dapat memberikan cahaya ketika malam tiba dan seperti ayam jago yang berani dengan kehidupan ini. Ini lagi aku ku beri tanda dengan darah ayam mentah, jangan marah menggerutu ini sudah ada bagiannya masing-masing. A,, kalau ada orang yang tidak jelas jangan menganggu, ini udah ada bagiannya seperti, tembakau, rokok, kapur, sirih, yang nantinya untuk di makan yang di balas dengan rezeki. Sekarang aku beri sebatang kue pulut seperti Langir (pohon dengan batang yang keras) yang digunakan sebagai tumpuan rumah agar jangan roboh ke bawah. Satu, dua, tiga, empat, lima, enam, tuhuh, aku berseru kepada Tuhan minta tolong sekarang mau memberikan nama pada bayi yang bagus seperti perjalanan hidupnya yang akan datang, nian nama yang sudah disiapkan (Fransiskus Januardi). Ya ini Tuhan acara Batalah (pemberian pada nama bayi) ini sudah dipengujung, sekarang mau berpisah dengan sanak saudara, kalau perkatan ku yang salah seperti petir yang panggil hujan, aku minta maaf kepada mu Tuhan. Aa,,, ini aku berterima kasih banyak ke Tuhan, sampai disini permintaan ku kepada mu Tuhan. Satu, dua, tiga, empat, lima, enam, tujuh (wawancara responden bapak Andot, 2021)".

\section{E. Makna Mantra Batalah}

Mantra pada umumnya tidak terlepas dari namanya kata-kata yang berbau mistik. Makna mantra diungkapkan oleh Keraf (Zulfahita, 2020:154) merupakan sebuah kata dan kalimat yang di dalamnya mengandung maksud serta tujuan di setiap kata-kata atau arti tersendiri, sehingga menghasilkan sebuah ide yang baik, Makna yang terkandung dalam mantra Batalah. Makna tersebut sebagai pemberian nama yang sah di mata Tuhan (Jubata) dan di mata Nenek Moyang, di kehidupan nyata manusia, selain itu juga sebagai pelindung bagi anak tersebut. Dalam pemberian nama tersebut di dapati adanya upacara pembacaan mantra yang dilakukan oleh Dukun (orang pintar) pembacaan ini tidak sembarangan melainkan sebagai sarana komunikasi kepada Tuhan (Jubata) untuk meminta restu terhadap bayi yang akan diberi nama. Oleh karena itu di upacara Batalah ini sangat penting bagi masyarakat di Desa Pauh Kabupaten Landak Kalimantan Barat, upacara Batalah ini termasuk dalam kategori budaya atau adat yang dijaga serta di lestarikan oleh Masarakat Suku Dayak Kalimantan Barat.

\section{F. Fungsi Mantra Batalah}

Sebagaimana diketahui setiap mantra apapun jenis dan bentuknya secara teoretis memiliki fungsi dalam kehidupan manusia. Menurut Edi dan Mulyanto, (2017:82) Mantra pada dasarnya memiliki berbagi fungsi atau kegunaan. Fungsi mantra tersebut antara lain sebagai fungsi sosial yang dipergunakan dalam kehidupan masyarakat. Terdapat beragam fungsi mantra di antaranya sebagai alat pengesahan pranata dan kebudayaan, sebagai alat pemeliharaan norma-norma masyarakat dan sebagai alat pengobatan tradisional. Fungsi mantra bagi masyarakat Suku Dayak Kalimantan Barat sebagai: (1) Komunikasi dengan Tuhan (Jubata) atas apa yang di minta, (2) Komunikasi dengan nenek moyang atas apa yang di minta, (3) Penangkal roh kejahatan, (4) Penghantar roh manusia ke alam arwah, (5) Sebagai kekuatan gaib, (6) Pengisi semua upacara adat, (7) Penawar racun, (8) Penambah kekuatan/kebal, (9) Membuka penglihatan untuk melihat roh-roh jahat, (10) Pemikat lawan jenis, (11) Santet, (12) Pengusir binatang buas, (13) Penjaga rumah, (14) Penjaga kampung, (15) Memberkati tanah untuk perkebunan.

Fungsi mantra Batalah bagi masyarakat di Desa Pauh Kabupaten Landak Kalimantan Barat. Dalam kepercayaan suku Dayak, upacara adat Batalah adalah bagian yang sangat penting sehingga mempunyai fungsi tersendiri dari upacara adat lainnya. Fungsi tersebut antara lain, yaitu: (1) Komunikasi dengan Tuhan (Jubata) atas apa yang di minta, (2) Komunikasi dengan nenek moyang atas apa yang di minta, (3) Sebagai bentuk pelastarian adat dan budaya, (4) Bentuk perlindungan pada bayi, (5) Bentuk nama yang sah dan (6) Menjaga rasa kekeluargaan.

\section{G. Nilai Mantra Batalah}

Nilai merupakan tingkah laku yang ada pada sistem yang di anut oleh manusia yang bersifat kongkrit sehingga bisa memberikan arti (kepercayaan manusia yakini) Nilai mantra Batalah bagi penduduk Desa Pauh Kabupaten Landak Kalimantan Barat dikategorikan dua bagian yaitu: Nilai religi, nilai ini terdapat di dalam mantra Batalah, karena dalam setiap kata-kata mantra pada mantra Batalah memiliki kekuatan gaib atau supernatural. Nilai religi yang terkandung dalam mantra Batalah ialah adanya kepercayaan masyarakat terhadap Tuhan (Jubata), melalui Jubata inilah, Dukun (orang pintar) berkomunikasi meminta berkat atau perlindungan atas bayi yang diberi nama seperi nama "Fransiskus Januardi".

\section{H. Norma Mantra Batalah}

Norma dalam adat-istiadat merupakan alat yang digunakan sebagai pengawas dan pemaksa, 
agar aturan-aturan dalam masyarakat dan aturan dalam kata-kata mantra bisa di patuhi. Dapat disimpulkan dalam pelaksanaan upacara adat merupakan aturan yang harus dilakukan, dimana sifat yang dimiliki oleh norma adat bisa membuat orang menghormati dan melestarika, karena adat tersebut pemberian dari nenek moyang, maka dari itu sebagai penerus di tuntut bisa menjag, melestariakan dan mengormati norma-norma di dalamnya (Oktaviani, 2018:10), Peraturanperaturan atau norma yang terkandung di dalamnya, salah satunya norma Batalah (pemberian nama pada bayi) di masyarakat suku Dayak. Upacara Batalah di masyarakat Desa Pauh Kabupaten Landak Kalimantan Barat sangat mempercayai.

\section{SIMPULAN DAN SARAN}

\section{A. Simpulan}

Berdasarkan hasil seluruh penjelasan yang sudah di jelaskan, maka kesimpulan yang kemukaan dari penjelasan penelitian tentang Mantra Batalah sebagai Tradisi Lisan pada Masyarakat Suku Dayak di Kabupaten Landak Kalimantan Barat dalam presfektif Antropolinguistik yaitu: Upacara Batalah merupakan upacara yang dilakukan untuk pemberian nama pada bayi yang telah lahir agar memiliki perlindungan dari Tuhan. Performansi berdimensi transcendent karena kehidupan di dunia nyata selalu berhubungan antara Tuhan dan manusia, manusia dan alam. Makna yang terkandung dalam mantra Batalah adalah sebagai pemberian nama yang sah di mata Tuhan (Jubata) dan di mata Nenek Moyang, sebagai pemberian nama yang sah di kehidupan nyata manusia, dan sebagai nama pelindung. Fungsi mantra di antaranya sebagai alat pengesahan pranata dan kebudayaan, sebagai alat pemeliharaan normanorma masyarakat dan sebagai alat pengobatan tradisional. Nilai mantra Batalah terbagi dua bagian ialah nilai religi dan nilai sosial. Norma dalam mantra Batalah merupakan aturan yang terdapat di setiap kata-kata mantra.

\section{B. Saran}

Berdasarkan hasil penelitian, ada tiga saran yang dapat diberikan, yakni: (1) mantra merupakan salah satu jenis karya sastra puisi lama. Karya sastra ini sangat menarik sehingga patut dilestarikan dalam kehidupan manusia karena memiliki bentuk performansi, makna, fungsi, nilai dan norma dalam suatu budaya pada masyarakat, sehingga perlu dilestarikan; (2) mantra Batalah sebagai tradisi lisan masyarakat suku Dayak di Kabupaten Landak Kalimantan Barat dapat digunakan sebagai sarana pendidikan karakter bagi masyarakat suku Dayak agar menjadi manusia yang arif dalam menjalani hidup dan kehidupan di dunia ini; (3) untuk penelitian selanjutnya yaitu penelitian terhadap mantra dalam upacara ritual Batalah dapat dikaji dari perspektif selain perspektif antropolinguistik, misalnya perspektif semiotik. Selain itu, untuk memperoleh hasil yang maksimal dalam melakukan penelitian sastra khususnya sastra lama, ketepatan dalam memilih sumber data adalah sesuatu yang niscaya.

\section{DAFTAR RUJUKAN}

Edi, S dan Mulyanto. 2017. Bentuk dan Fungsi Teks Mantra. Kadera Bahasa, (Online), Vol. 9, No.2 (https://kaderabahasa.kemdikbud.go.id/jurnal/ index.php/kaderabahasa/article/download/7/7 , diunduh 21 juni 2021).

Jumadi, dkk. 2017. Antropolinguistik dalam Mantra Dayak Maanyan di Kalimantan Selatan (Antropolinguistics in Maanyan Mantra in South Kalimantan). Jurnal Bahasa, Sastra, dan Pembelajarannya. (Online), Vol. 7, No. 1, (http://download.garuda.ristekdikti.go.id/articl e.php?article $=733513 \&$ val $=11507$ \&title=, diunduh 21 April 2021).

Munawarroh, A. 2016. Fungsi Sosial Tradisi Mandoa dalam Upacara Kematian (Studi Kasus: Nagari Pauh Duo Nan Batigo, Kecamatan Pauh Duo, Kabupaten Solok Selatan). Skripsi, (Online), Program Studi Bahasa Indonesia, Fakultas ilmu Sosial dan Politik, Universitas Andalas, Padang, (http://scholar.unand.ac.id/4586/2/BAB\%201. pdf, diunduh 2 Maret 2021).

Oktaviani, D. 2018. Analisis Bentuk, Fungsi, dan Makna Mantra Suku Sasak di Desa Jelantik Lombok Tengah dan Hubungannya dengan Pembelajaran Sastra di SMA. Skripsi. (Online), Program Studi Pendidikan Bahasa Sastra Indonesia dan Daerah, Jurusan Pendidikan Bahasa dan Seni, Fakultas Keguruan dan Ilmu Pendidikan, Universitas Mataram

(http://eprints.unram.ac.id/5054/1/JURNAL\%2 0DIAN\%20PDF.pdf, diunduh 22 Juni 2021).

Priskila, H. 2010. Tradisi Naik Dango Suku Dayak Kanayatn Kajian Asal Usul, proses ritual, Fungsi dan Nilai. Skripsi, (Online), Program Studi Bahasa Indonesia,Fakultas sastra Universitas Sanata Dharama Yogyakarta, (https://repository.usd.ac.id/25455/2/044114 031_Full\%5B1\%5D.pdf , diunduh 1 
Maret 2021).

Sibarani, R. 2015. Pendekatan Antropolinguistik Terhadap Kajian Tradisi Lisan. Retorika: Jurnal Ilmu Bahasa, (Online), Vol. 1, No. 1 ,

(Https://Www.Researchgate.Net/Publication/3 14969256 Pendekatan Antropolinguistik Terha dap Kajian Tradisi Lisan, diunduh 10 April 2021).

Yogi, F. dkk. 2019. Peristilahan dalam Acara Batalah Masyarakat Dayak Kanayatn Bahasa Ahe. Jurnal pendidikan dan pembelajaran, (Online), Vol. 8, No. 6, (http://jurnal.untan.ac.id/index.php/jpdpb/arti cle/view/33804, diunduh 26 Febuari 2021).

Zulfahita. 2020. Struktur, Fungsi, Dan Makna Mantra Pengasih Diri Di Desa Sungai Nyirih, Kecamatan Selakau Serta Implementasinya Di Sekolah. Jurnal Pendidikan Bahasa, (Online), VOL. 9, NO. 2, (https://journal.ikippgriptk.ac.id/index.php/ba hasa/article/view/1951, diunduh 21 Juni 2021). 